\title{
Zurri Waqf Reporting: Preliminary Findings on Reporting Practices
}

Sri Wahyu Sakina Ahmad Sanusi, Mohd Fairuz Md. Salleh \& Salmy Edawati Yaacob

To Link this Article: http://dx.doi.org/10.6007/IJARAFMS/v11-i3/10720 DOI:10.6007/IJARAFMS/v11-i3/10720

Received: 30 June 2021, Revised: 29 July 2021, Accepted: 16 August 2021

Published Online: 27 August 2021

In-Text Citation: (Sanusi et al., 2021)

To Cite this Article: Sanusi, S. W. S. A., Salleh, M. F. M., \& Yaacob, S. E. (2021). Zurri Waqf Reporting: Preliminary Findings on Reporting Practices. International Journal of Academic Research in Accounting Finance and Management Sciences, 11(3), 235-255.

Copyright: (c) 2021 The Author(s)

Published by Human Resource Management Academic Research Society (www.hrmars.com)

This article is published under the Creative Commons Attribution (CC BY 4.0) license. Anyone may reproduce, distribute, translate and create derivative works of this article (for both commercial and non-commercial purposes), subject to full attribution to the original publication and authors. The full terms of this license may be seen at: http://creativecommons.org/licences/by/4.0/legalcode

\section{Vol. 11, No. 3, 2021, Pg. 235 - 255}

Full Terms \& Conditions of access and use can be found at http://hrmars.com/index.php/pages/detail/publication-ethics 


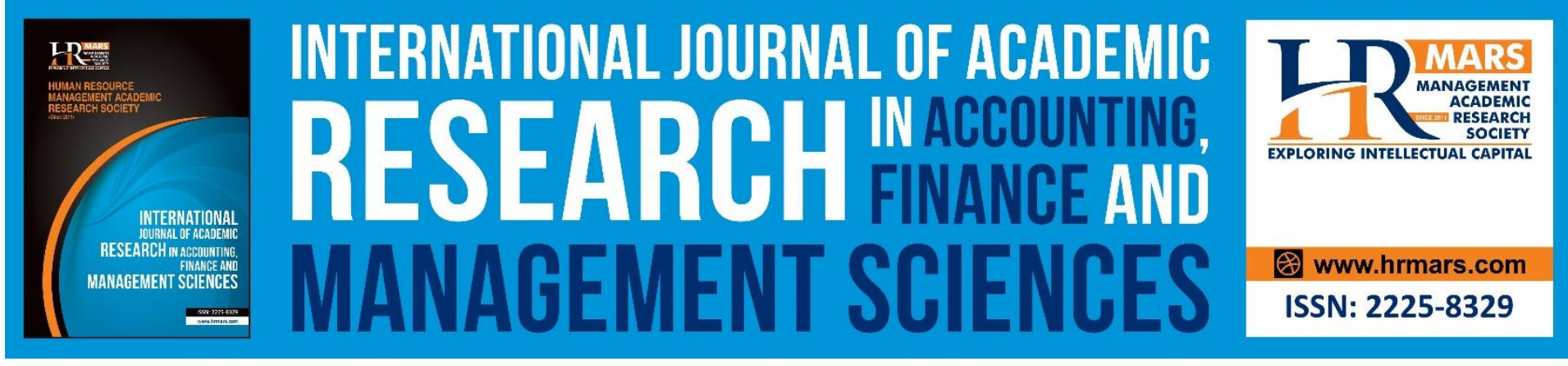

\title{
Zurri Waqf Reporting: Preliminary Findings on Reporting Practices
}

\section{Sri Wahyu Sakina Ahmad Sanusi, Mohd Fairuz Md. Salleh \& Salmy Edawati Yaacob}

Ph.D Researcher, Institut Islam Hadhari, Universiti Kebangsaan Malaysia, Bangi, Selangor, Malaysia. She is also an accounting lecturer, Faculty of Management \& Muamalah, Kolej Universiti Islam Selangor (KUIS), Bandar Seri Putra, 43000, Kajang, Selangor Darul Ehsan. (Ph.D), Associate Professor, Graduate School of Business (GSB), Universiti Kebangsaan Malaysia, Bangi, Selangor, Malaysia, (Ph.D), Associate Professor, Institut Islam Hadhari, Faculty of Islamic Studies, Universiti Kebangsaan Malaysia, Bangi, Selangor, Malaysia.

Email:sriwahyu@kuis.edu.my, fairuz@ukm.edu.my, salmy1001@ukm.edu.my

\begin{abstract}
Islamic wealth management is significant to ensure the heirs may survive after losing their loved ones. Therefore, zurri waqf is one of the instruments which can be implement to ensure the perpetual of the family's equity. For instance, if the zurri waqf asset is a land, it could be developed to be an impactful asset than can generate revenues which can be distributed among the heirs. For that matter, the trustee appointed is accountable to the management of zurri waqf which consists of accounting as well. In Malaysia, zurri waqf have been implemented in few states and the heirs are still available for the revenue's distribution. However, a specific standard has yet to be developed in the context of zurri waqf in Malaysia. Hence, this paper aims to examine the reporting of zurri waqf in Malaysia and to suggest the minimum reporting item of zurri waqf in the annual report. Qualitative data analysis which referring to content analysis and semi-structured interviews was adopted for the methodology. Sample involves 4 SIRCs annual report which involve in zurri waqf management and duration covered is 5 years which is from the year 2014-2018. Meanwhile, the respondents consist of 5 respondents which comprise heads of waqf units and accountant from 4 SIRC. The paper found that there are inconsistencies on the accounting treatment among 3 SIRCs in recognition and disclosure in zurri waqf reporting though the practices have been in place for centuries. The current disclosure needs to be improved. In addition, the zurri waqf implementation in Malaysia is not proactive yet and there is a lacking in reporting aspects. Nonetheless, the significance of reporting shall be prioritize given the Quran narration and relevant accounting theories related to accountability and justice to the stakeholders. The findings are preliminary and highlight the issue of current zurri waqf accounting practices in SIRCs. Therefore, it requires meticulous follow-up to form a complete picture of zurri waqf reporting that would assist administrators to improve their policies toward better quality disclosure in order to convince the public to participate in zurri waqf which qualifies as a property planning instrument. Having said that, future research is
\end{abstract}


MANAGEMENT SCIENCES

Vol. 11, No. 3, 2021, E-ISSN: 2225-8329 @ 2021 HRMARS

recommended to develop practical accounting treatments which suit the nature of zurri waqf as well as compliance with current accounting standards.

Keywords: Waqf Zurri, Family Waqf, Disclosure, Reporting, Family, Assets

\section{Introduction}

According to Islamic history, zurri waqf is used as a property planning tool or family inheritance plan. Zurri waqf aims to defend the plight of families whose parents are helpless. In the concept of Islamic law, those who own property and intended to implement waqf should give priority to their immediate family members. Wealth management is indeed an important issue to be solved immediately after the death of a parent or guardian. It is hoped that the inherited property of the family and its descendants can bring persistent and unlimited benefits. This is one of the main criteria available in zurri waqf, and it is different from other existing instrument in property management. According to Islamic law, the methods of managing or distributing property are; farai'd (as stipulated in the Quran), wills and hibah (giving). However, the applicability of this method varies according to the actual situation and the actual situation, depending on the situation and the problems faced.

In addition, if someone is eager for help; then it is better to give zurri waqf to those in need (Tjek Tanti, 2013)

In light with this hadith:

"Leave the children and wives with wealth is better than leave them in the hardship circumstances"

Rasulullah s.a.w mentioned that it is better if we bequeath our family with wealth to enable them to live even though the backbone of the family passed away. We should avoid leaving them with nothing as this might urge them to search for financial assistance from others. Thus, zurri waqf is one of the instruments that can be implement in this situation as the wealth bequeathed can be utilised to generate income and assist the family and the descendants to survive.

Table i : Narration of Al-Quran regarding deeds among families

\begin{tabular}{|l|l|}
\hline Name of surah / hadith & Narration \\
\hline Ali Imran :92 & $\begin{array}{l}\text { You will never achieve righteousness until } \\
\text { you donate some of what you cherish. And } \\
\text { whatever you give is certainly well known to } \\
\text { Allah. }\end{array}$ \\
\hline Al-Maidah : & $\begin{array}{l}\text { Cooperate with one another in goodness } \\
\text { and righteousness, and do not cooperate in } \\
\text { sin and transgression. And be mindful of } \\
\text { Allah. Surely Allah is severe in punishment. }\end{array}$ \\
\hline $\begin{array}{l}\text { Abi 'Abdullah Muhammad bin Ismail, (2002). } \\
\text { Sahih al-Bukhari }\end{array}$ & $\begin{array}{l}\text { Leaving children and wives in luxury are } \\
\text { better than leave them in hardship }\end{array}$ \\
\hline
\end{tabular}


MANAGEMENT SCIENCES

Vol. 11, No. 3, 2021, E-ISSN: 2225-8329 ๔ 2021 HRMARS

According to the above table, it can be concluded that Islam demanded kindness among families, relatives and society by giving up the wealth we have. If zurri waqf assets are fully utilized and can generate income, rewards should be given and families should be protected from poverty. In addition, if a person leaves the heir, then life in a wealthy state is better than life in difficult situations that rely on the sympathy of others. The basis of zurri waqf may be the basis for expanding property interests, which in turn may result in the beneficiaries continuing to make use of the proceeds. Benefits can be fully utilized by not only their families and descendants, but other Muslims as well. Zurri waqf has been practiced and successful in several countries, including Singapore, Kuwait, Turkey, and Syria; demonstrating that this noble practice will be continued due to its unique characteristics in asset preservation and continuous revenue generation.

\section{Malaysia's family (zurri) waqf practices}

Currently, there is no objection from Malaysian law and madzhab (Islamic principles) in the execution of zurri waqf. It has become a matter of practice for Malaysia to treat it as a matter of urgency as it is allowable to be practice in Malaysia (Suhaimi, 2018). The source of power of Islamic administration and its affairs in Malaysia has been outlined in Article 3 of the Malaysian Constitution. It sets out the powers of the affairs of religion and Malay customs, which put the rights of the Malay rulers and the state government respectively (Siraj, 2012). Based on this, all waqf administration matters are under the State Islamic Religious Council (SIRC) which is found in all 14 states in Malaysia. SIRC is responsible for being the sole trustee for the waqf assets.

The zurri waqf that exists in Malaysia has started decades ago and its administration is placed under SIRC because it is an independent religious institution and has no interest in the waqif. Although there is a rotation of staff, but with the asset registration document, it legalized the authority of SIRC as a trustee. This trust is expressed in Surah Al-Anfal verse 27 which means:

'O believers! Do not betray Allah and the Messenger, nor betray your trusts knowingly. $O$ you who have believed, do not betray Allah and the Messenger or betray your trusts while you know [the consequence].'

Moreover, zurri waqf in Malaysia saw the early practice of zurri waqf in Kelantan during 1921. While in Terengganu, there are as many as 26 lots of land reported on waqf zurri property. This followed by two states located in northern Malaysia namely Pulau Pinang and Kedah whereby the assets proceeds are still being operating. This shows that the presence and implementation of waqf zurri in Malaysia is still important today. Having said that, with regard to the new developments related to zurri waqf in Malaysia under the Islamic Services and Securities Act Labuan 2010-2012, Muslims are permitted to use the Labuan International Waqf Foundation (LIWF) to set up a trust unit based on the concept of zurri waqf (Sadique 2018). Thus, Muslims intend to implement zurri waqf can use the LIWF service to assist them in the implementation of zurri waqf to ensure that the benefits reach qualified recipients.

Although the zurri waqf narrow into the intent of the family; the preparation of reports is vital and is considered to visualize the stewardship role of the preparer either (SIRC) or third parties, such as the foundation or cooperatives. Any transactions involving economic capital, in particular those of the family, need to be properly recorded, as they will support the 
MANAGEMENT SCIENCES

Vol. 11, No. 3, 2021, E-ISSN: 2225-8329 @ 2021 HRMARS

forthcoming decision on asset development in other to produce more income to be segregated between beneficiaries. As proper reporting requires the implementation of accounting theories that are fundamental to the accounting process; zurri waqf reporting need to comply the application of accounting theories.

\section{Context of the Study}

Reporting is an activity chain that provides information on how a non-profit organization uses the fund (Li et al., 2020). It is a medium for self-defend upon answering to society on how the fund being managed and output achieved to date on the basis of the fund. Non-profit organizations strengthen donors' positive attitudes and actions by ensuring that donors assist them in any matters (Kelly, 2001b). Reporting is a non-stop enforcement, aimed at reminding donors that the non-profit sector is making progress so far (Li et al., 2020).

The importance of non-profit or charity reporting has been discussed (Breckell et al., 2011; Hyndman \& McConville, 2016; Li et al., 2020) to reflect the funders' values as well as the relationship between the funders and the charity entity. In terms of avenues for organizations such as profit and non-profit entities to communicate with their stakeholders, annual reports are well-known as popular ways for management to fulfil their reporting responsibility' (FASB, 1975) and duty of accountability as well as stewardship (Charity Commission, 2000).

Furthermore, charity reporting has an advantage in engaging and motivating external shareholders in terms of bonding with donors, representing value to funders, and attracting new support (Breckell et al., 2011). In such difficult economic times, charitable spending performance and transparency in reporting can be especially important to a wide range of stakeholders. Transparency is discussed and contextualized within the context of stakeholder theory, examining why charities may need to reveal the reporting and the significance of providing data on performance. Embracing the thrusts principle also inspires charities to communicate effectively with stakeholders, reporting useful, good-exceptional data that is accessible to and assessable by the audience. Such participation may benefit the organization, with empirical evidence indicating that, in non-profit organizations, obvious reporting can inspire similarly funding, lower agency costs, and contribute to a positive social outcome (Hyndman \& McConville, 2016).

A broad body of empirical research on transparency or disclosures in non-profit organisations points out that transparency in annual reports is an essential tool for managers to communicate the activities and results of their organisations to other organisations (Healy \& Palepu, 2001; Hossain \& Hammami, 2009). In this sense, Latridis (2011) found that disclosure is important because managers are usually kept responsible for achieving certain business and financial goals. Transparency in annual reports is an essential tool for managers to communicate the activities and results of their organizations to other organizations, according to a large body of empirical research on transparency or disclosures in non-profit organizations (Healy \& Palepu, 2001; Hossain \& Hammami, 2009).

In this regard, Latridis (2011) discovered that disclosure is important because managers are typically held accountable for meeting certain business and financial objectives.

After delving into the significance of reporting in terms of transparency, there is no doubt that zurri waqf reporting is highly claimable to be completed. Although it is not intended for the 
MANAGEMENT SCIENCES

Vol. 11, No. 3, 2021, E-ISSN: 2225-8329 @ 2021 HRMARS

general public, it is still necessary to prepare the reporting in order to track the activities, income, expenses, and surplus of waqf zurri assets. Many decisions can be made and proper future planning can be implemented based on the reporting. For example, if the asset is land developed for agricultural purposes, the expenses associated with it, as well as the income derived if it has been harvested, must be reported and disclosed. The society that monitors the efficiency of these activities through reporting may have been enticed to practice waqf zurri as well because they knew that the benefits or yield from asset operation would be distributed to their heirs and, indirectly, to Muslims.

When the person in charge of the reporting is no longer in service, the reporting serves as concrete evidence. By referring to the current reporting, the new person in charge will be able to continue the zurri waqf reporting. If no reporting is made on the development of waqf zurri assets, it will be difficult to find and trace previous transactions. Without proper reporting, it is impossible to track the inflow and outflow of transactions. As a result, the process of allocating the yield from asset utilization would go haywire, leading to misleading transactions. As a result, reporting helps in a variety of ways to track past, present, and future results, as well as returns on assets or property projects.

The sufficiency of information disclosed and presented in the annual report pertaining to zurri waqf matters is questionable. Who will be interested in reviewing the data? Is it SIRC's management? Is it the family's heirs or descendants who are the beneficiaries? Or is it the other stakeholders who have an indirect interest in the development and performance of the waqf zurri assets? Until today, information presented and disclosed by SIRC has varied due to the lack of a specific standard governing waqf zurri matters. The data will be discussed in greater detail in the results section.

Furthermore, accountability is always an issue between the endower party and the administration party. According to the syariah, those in charge of monetary assets are required to submit an account of their stewardship, regardless of whether the transactions and assets in question are handled by governments, commercial enterprises, or non-profit organizations. Furthermore, regardless of the nature of the transactions and assets, whether profit or non profit entity, anyone involved in financial assets is required to prepare an account or document for the performance of a stewardship duty (Hassan \& Nabihah, 2010).

However, the accounting needs of non-profit institutions such as zurri waqf have yet to be questionable. As mentioned in verse 282 of Al Baqarah:

As stated in Al Baqarah verse 282:

"O you who have believed, when you contract a debt for a specified term, write it down. And let a scribe write it between you in justice. Let no scribe refuse to write as Allah has taught him. So let him write and let the one who has the obligation dictate".

The critical aspects of reporting have been highlighted, and as Muslims, it has become the Khalifa's duty to act as an obligation to act. On the day of judgment, everything will be requested as a trustee; it will be required to perform the zurri waqf deeds as well as how the assets or resources will be used to ensure that the benefits received can be allocated to the beneficiaries. It may not be as stringent as IFRS; however, the material disclosed should be 
MANAGEMENT SCIENCES

Vol. 11, No. 3, 2021, E-ISSN: 2225-8329 @ 2021 HRMARS

capable of representing the status of the assets assigned to it in order to assess the effectiveness of asset production and the surplus of activities in asset production to be allocated to beneficiaries.

There has been no comprehensive disclosure of waqf assets and liabilities, revenues and expenses by the councils to date (Daud, 2019). Previous findings have revealed flaws in the preparation of waqf accounts, outdated data, and longer preparation times for financial reports, among other things (Abdul Rahim et al.,1999; Md. Zain, 2005; Masruki and Shafii, 2013). The absence of a standard for waqf accounting and reporting has been linked to the absence of a proper accounting record (2013: Masruki \& Shafii). The increasing number of waqfs today, which represents an enormous amount of waqf assets that can be developed and contribute to socioeconomic development, has highlighted the importance of having good accounting and reporting standards for waqfs (Talib et al, 2018).

As a result, the purpose of this paper is to:

1. examine the disclosure and presentation of waqf zurri in Malaysia, and

2. suggest the minimum items for disclosure and presentation of waqf zurri in the annual report.

\section{Methodology \\ Sample size and data collection}

This article employed a qualitative approach in which data collection is conducted through interview sessions with identified respondents, as well as observations and scrutiny of the SIRC's annual report for the period of 5 years. This article is intended to describe the accounting practices of zurri waqf in SIRC. The sample of this study is using data from 3 SIRC selected using purposive sampling method. Secondly, data collection method used in this study is the content analysis of the SIRC financial statements from the year 2014 until 2018 as this is the most recent annual report that SIRC can provide to observe the components of zurri waqf that are recognized and disclosed among the selected sample of SIRC. Therefore, this analysis includes 3 SIRC that manages zurri waqf. The years involved are from 2014 to 2018. The period coverage takes into account the compliance of MPERS in 2014 and the transition of MPSAS in 2017. This is the appropriate period chosen after considering the transition of accounting standards situation.

Data is scarce because zurri waqf practices are not aggressively practised in Malaysia, but the values of zurri's assets development is significant as it still being allocated to the endower's generations. As a result, samples come to a halt at the data saturation point. Data saturation refers to the point at which information becomes repetitive and the researcher will not discover any new findings from additional data collection (Kyngäs, 2020). In conjunction with this study, the sample size is based on Morse (2000), who argued that the sample size will depend on the following factors: the scope of the research question (the broader the scope, the larger the sample size required); the nature of the issue (the more 'obvious' the issue, the smaller the sample size); and the quality of the data (the richer the data, the smaller the sample size). As a result, even though the sample size is small, the data obtained is sufficient to guide a larger study in the future. 
MANAGEMENT SCIENCES

Vol. 11, No. 3, 2021, E-ISSN: 2225-8329 @ 2021 HRMARS

Researchers made an appointment to conduct an interview session with SIRC's officers consists of waqf head unit and accountants. A total of 5 respondents from 3 SIRC were interviewed and at the time taken was around one to two hours for each meeting. Respondent is namely as $A, B, C, D \& E$.

Table ii: List of respondent

\begin{tabular}{|l|l|l|}
\hline Respondent & Institution & Position \\
\hline$R-A$ & SIRC - X & Head unit of waqf \\
\hline$R-B$ & SIRC - Y & Head unit of waqf \\
\hline R - C & SIRC - X & Accountant assistant \\
\hline R - D & SIRC - Z & Head unit of waqf \\
\hline$R-E$ & SIRC - Z & Accountant \\
\hline
\end{tabular}

The data were transcribed after the interviews were conducted. The first task in the analysis is to identify the corresponding category once the data are collected. The categories are then linked to create a theme from a full source. This topic comprises all the important information used during the case study. The data is then edited, redundancies are compiled and results are obtained. Patton explains that there is no accurate point for finishing and analyzing data. Although analyzes and interpretations are clearly separated from each other in practice. Ideas on analysis and interpretation arise during data collection.

Content analysis was applied to efficiency information in the annual report and websites. In an effort to facilitate a systematic, objective and reliable analysis of such mixed data, a detailed checklist and analysis guidance has been developed with clear examples and guidance to assist in the categorization of data (Krippendorff, 2013). The content analysis was then applied to all material collected, categorised and encoded by reference to a specially developed checklist of predefined categories in order to identify patterns in that report. (Krippendorff, 2013). Each sentence, headline, table and diagram has been categorised as including framework measures or not.

\section{Development of the zurri waqf items for disclosure and presentation}

The disclosure indexes adopted in this study is from Vinnicombe (2012) whereby the compliance is not merely looking at standard line by line basis. This study measures conformity largely in relation to Manual Pengurusan Perakaunan Wakaf (MPPW) (2009) which contrary to many studies that complies with the IASB's reporting norms, in which compliance is measured by standard to a large extent and with most or all of the standards contained in the index. This manual has been developed by particular authorities' body who held accountability on waqf management in Malaysia. MPPW has given a guide on waqf accounting in which each of SIRC shall prepare:
i. Statement of financial position
ii.Statement of comprehensive income
iii.Statement of changes in equity
iv.Statement of cash flow
v. Notes to the account

The specific compliance is required since zurri waqf accounting is not specifically govern in current accounting standard. Therefore, this manual (MPPW) is designed to provide a better 
MANAGEMENT SCIENCES

Vol. 11, No. 3, 2021, E-ISSN: 2225-8329 @ 2021 HRMARS

insight into waqf accounting overall compliance. Despite using this manual as a guide to measure the conformity of zurri waqf accounting disclosures, this study adopted Md Salleh et al., (2016) whereby the proposed disclosure items cover all aspects of waqf management in terms of receipt of waqf assets, development and investment of waqf property. Disclosure items related to waqf are important so that the institution can clearly show that waqf property has been preserved and well managed in accordance with the achievement of maqasid shariah.

Therefore, this study develops an enhancement of the zurri waqf accounting disclosure which tailored to the zurri waqf features and significance to the stakeholders. The operational checklist is presented as shown in table below so that a deductive, mechanistic approach (Beck, Campbell, \& Shrives, 2010) was adopted in the analysis.

Table iii: Checklist of items analyzed

\begin{tabular}{|l|l|}
\hline Num & Checklist \\
\hline 1. & Waqf zurri assets development \\
\hline 2. & Revenues on waqf zurri \\
\hline 3. & Allocation to beneficiaries \\
\hline 4. & Types of zurri waqf assets \\
\hline
\end{tabular}

Sources (Md Salleh et al, 2016; Gandia, 2011; MPSAS, 2013, Author, 2021).

The annual report and websites were manually reviewed in to determine the effectiveness of the information related to each sentence, headline, table, and diagram (Beattie \& Thomson, 2007) classified as efficiency-related or not. In the data collection, information containing efficiency-related information has already been identified. The annual reports of three SIRCS have been thoroughly reviewed and analysed in order to match four elements mentioned in the index. Throughout the process, meticulous checks were performed to ensure that there were no omissions in the significance of the elements.

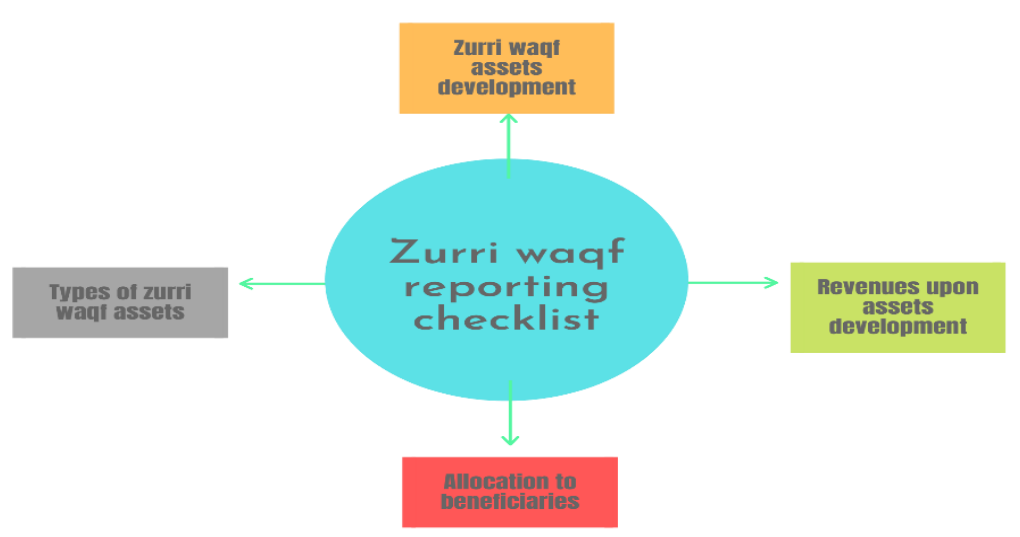

Figure i:Items for zurri waqf reporting disclosure 
MANAGEMENT SCIENCES

Vol. 11 , No. 3, 2021, E-ISSN: 2225-8329 @ 2021 HRMARS

\section{Result and Discussion}

The following is a preliminary analysis of the annual reports of three SIRCs that manage zurri waqf. The period covers from year 2014 to 2018. Since this is a preliminary finding, the most recent annual report available is used in this paper. All accounts must be audited and must adhere to the established standards. It's just that there are no specific standards or guidelines for zurri waqf. As a result, there is no consistency in reporting.

Table below presented content analysis on the annual report of 3 SIRCs:

Table iv: Content analysis of SIRC (X)

\begin{tabular}{|c|c|c|c|c|c|c|}
\hline & & 2014 & 2015 & 2016 & 2017 & 2018 \\
\hline $\begin{array}{l}\text { 1.Zurri waqf } \\
\text { recognition }\end{array}$ & $\begin{array}{l}\text { Land and } \\
\text { building }\end{array}$ & \multicolumn{5}{|c|}{ Recorded at token value (RM10) } \\
\hline Disclosure & $\begin{array}{l}\text { Notes to } \\
\text { the } \\
\text { account } \\
\text { - details } \\
\text { on assets } \\
\text { list }\end{array}$ & \multicolumn{3}{|c|}{$\begin{array}{l}\text { No waqf category in notes to the } \\
\text { account }\end{array}$} & \multicolumn{2}{|c|}{$\begin{array}{l}\text { There is a category of } \\
\text { general waqf, special } \\
\text { (khas) waqf in the } \\
\text { notes. }\end{array}$} \\
\hline
\end{tabular}

Table v: Content analysis of SIRC (Y)

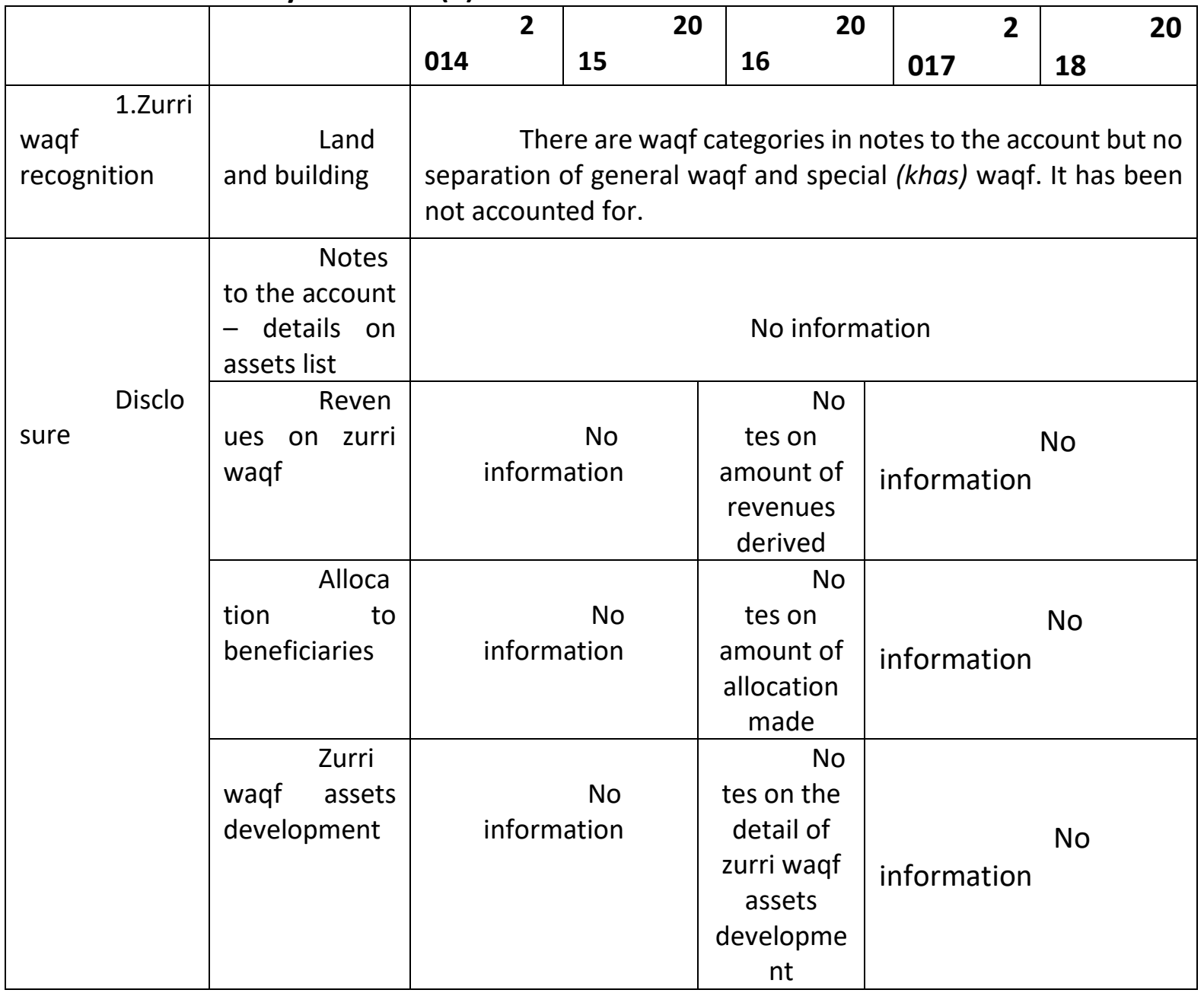


MANAGEMENT SCIENCES

Vol. 11, No. 3, 2021, E-ISSN: 2225-8329 @ 2021 HRMARS

Table vi: Content analysis of SIRC (Z)

\begin{tabular}{|c|c|c|c|c|c|c|}
\hline & & 2014 & 2015 & 2016 & 2017 & 2018 \\
\hline $\begin{array}{l}\text { 1.Zurri waqf } \\
\text { recognition }\end{array}$ & $\begin{array}{l}\text { Land and } \\
\text { building }\end{array}$ & \multicolumn{5}{|c|}{ It has not been accounted for. } \\
\hline Disclosure & $\begin{array}{l}\text { Notes to } \\
\text { the } \\
\text { account } \\
\text { - details } \\
\text { on assets } \\
\text { list }\end{array}$ & \multicolumn{3}{|c|}{$\begin{array}{l}\text { There is note on the details of waqf } \\
\text { property which consists of special } \\
\text { (khas) waqf category. It stated the } \\
\text { units and market value. }\end{array}$} & \multicolumn{2}{|c|}{$\begin{array}{l}\text { There is note on the } \\
\text { details of waqf } \\
\text { property which } \\
\text { consists of special } \\
\text { waqf/zurri category. It } \\
\text { stated the units and } \\
\text { market value. }\end{array}$} \\
\hline
\end{tabular}

Since the practise of zurri waqf is not actively implemented, only some of the SIRCs have registration and documentation on waqf zurri. The study focused on 4 disclosures and presentation items generally included in the MPSAS 1. However, it is tailored to the needs of zurri waqf in the transmission of information that is different from other waqfs. The elements which being look into is the waqf zurri activities in terms of assets development, any project or other activities which generates the income. Secondly is the revenue pertaining to the assets utilize by SIRC to ensure the income flows and can be used for allocation to the beneficiaries. Thirdly is the amount of allocation given to a list of beneficiaries. Finally, the disclosure of assets containing the types of waqf zurri assets, units and value shown in the notes to the accounts.

SIRC $X$ recognized waqf properties at the token value of RM10 per property received regardless of the market value of the property. However, this transaction did not being consolidate with SIRCs assets in the financial statement. For the disclosure, there is no information on the assets detail, revenues derived and allocation to beneficiaries from year 2014-2018. However, the separate category on waqf assets has been disclosed regarding general waqf and special waqf but still no information mentioning the zurri waqf.

SIRC Y did not recognize zurri waqf assets in the financial statement. Hence the information on the assets is untraceable. Even the notes to the account on the zurri waqf assets is not available. However, on the disclosure part, SIRC X has made specific disclosure regarding the total revenues derived and total allocation to the beneficiaries during 2016. The disclosure just merely on the total amount but not detailed per unit. Hence, the number of beneficiaries who received the proceeds is not available. In addition, details on zurri waqf assets development has been disclosed as well in 2016.

SIRC Z did not recognize the zurri waqf assets. The only information which proved the zurri waqf existence is the details on assets list in the notes to the account. From year 2014 until 2016 , there is a note on the details of waqf property which consists of special (khas) waqf category which stated the units and market value. During this year, the zurri waqf information is embedded in special (khas) waqf category. However, starting on 2017 until 2018, there is a note on the details of waqf property which consists of zurri waqf category which stated the 
MANAGEMENT SCIENCES

Vol. 11, No. 3, 2021, E-ISSN: 2225-8329 @ 2021 HRMARS

units and market value. Therefore, it clarifies the amount of zurri waqf assets handled by SIRC $Z$ and the measurement is reliable as it measures at market value.

The minimum disclosure or presentation of the relevant information is crucial to zurri waqf, and SIRC is considered to be the sole trustee responsible for the endower and the offspring. Disclosure of information is also crucial for organisations to gather information so that they are accountable to their stakeholders. (Greiling, 2010; Gandia, 2011; Ortega-Rodríguez,2020). These 4 elements are based on (Md Salleh et al, 2016) which suggest that the disclosure or procedure of assets covers all aspects of the management of waqf, including acceptance of waqf, retention of waqf, development or investment of waqf property and exchange (istibdal) of waqf property. This requirement is intended to preserve the survival of the heirs or descendants of the endower.

As mentioned in An-nisa verse 135;

O believers! Stand firm for justice as witnesses for Allah even if it is against yourselves, your parents, or close relatives. Be they rich or poor, Allah is best to ensure their interests. So do not let your desires cause you to deviate 'from justice'. If you distort the testimony or refuse to give it, then 'know that' Allah is certainly All-Aware of what you do

Allah commands His servants, to uphold justice, and do not turn away from justice, do not delay from upholding justice, for God is only because of the mistakes of those who dissuade, do not influence them by anything that makes them turn away from justice. They're supposed to help each other, cooperate, support each other for the sake of justice ${ }^{1}$

The importance of justice and cooperation is highlighted as a significant value among Muslims in this translation. Consequently, with regard to the disclosure in the zurri waqf report; the party responsible shall have justice towards the endowers and the beneficiaries, while cooperation between them is essential to the achievement of the fine information to be presented in the annual report.

On the basis of the above analysis, it can be concluded that there is room for improvement and that the structure of the accountable party needs to be reshaped. Even the zurri waqf focused on the family per say, but if the value of the waqf assets is growing and significant; somehow, or rather, the benefits indirectly will reach society as a whole. For example, if the asset is land that is transformed into plantation, it will create employment and help the economy to grow. That is why the impact of waqf zurri is definitely not on the family per se. Second, it can be suggested that waqf zurri in Malaysia could make practise in Singapore as a benchmark for zurri waqf reporting. Zurri waqf shall be treated as a single unit per se based on trust deed rather than consolidation in a single waqf fund.

"The following wakaf funds are set up under Sections 58 and 49 of the Administration of Muslim Law Act, Chapter 3. Each fund is administered in accordance with the terms and objects set out in its trust deeds" (MUIS, 2019)

In addition, the disclosure and presentation of income from waqf zurri must consist of a list of any income received from the proceeds of the assets developed and any expenses incurred in connection with it. Output from this would be the fund used for the allocation to the beneficiaries. This aspect, in particular, needs to be meticulous and transparent, as the

\footnotetext{
${ }^{1}$ Tafsir Ibn Khatir n.d, narrated by Al Imam Abul Fida,
} 
MANAGEMENT SCIENCES

Vol. 11, No. 3, 2021, E-ISSN: 2225-8329 @ 2021 HRMARS

surplus from it will be fully utilized to fulfil the deeds of the endower. This definitely requires a specific officer to handle as the task from another type of waqf is also burdensome.

As for the assets, liabilities and other items included in the balance sheet as the normal balance sheet. This is significant in terms of knowing the value of the assets at that point, given the liabilities that need to be settled. Finally, the remarkable point in both statements (i.e., surplus, assets and liabilities) is significant in the monitoring of the performance of waqf assets in the generation of income or income. Disclosure of income outcomes or surpluses was preferable as it would lead to an improvement in both the upward accountability of donors and the downward accountability of recipients (Benjamin, 2012; Connolly and Hyndman, 2013b). As in the case of waqf zurri, the responsibility rests with the family of endowers (representatives of the family) and the beneficiaries. It is therefore crucial to have disclosure and reporting in place, as the value of the assets is not stagnant and the generation of income is growing every year.

In short, the link between waqf zurri practises and reporting is literally obvious. Minimum reporting shall consist of disclosure and presentation, as it illustrated SIRC's accountability to the endower and the recipients. The diagram below depicted the relationship between zurri waqf and reporting.

Table vii: Recognition and disclosure of zurri waqf

\begin{tabular}{|c|c|c|}
\hline Respondent & Theme & Quotes \\
\hline R-A - SIRC X & \multirow{2}{*}{ Recognition } & $\begin{array}{l}\text { "zurri waqf item disclose in other } \\
\text { deposits for record, no notes to } \\
\text { the account... can't be see } \\
\text { clearly". }\end{array}$ \\
\hline R-D- SIRC Z & & $\begin{array}{l}\text { "For example, if the waqf asset is } \\
\text { the rental property... 99-year } \\
\text { lease, that amount is recognized } \\
\text { as SIRC's equity for investment". }\end{array}$ \\
\hline R-E- SIRC Z & \multirow{3}{*}{ Disclosure } & $\begin{array}{l}\text { "Most of the time, waqf dislosure } \\
\text { including zurri is combine in trust } \\
\text { accounts, we don't have specific } \\
\text { zurri waqf per se". }\end{array}$ \\
\hline R-C- SIRC A & & "annual report is for budget only" \\
\hline R-B- SIRCY & & $\begin{array}{l}\text { "disclosure is made to beneficiary } \\
\text { if they requested... current } \\
\text { financial statement } \\
\text { disseminate as well in financial } \\
\text { meeting with heirs, in } 3 \text { times per } \\
\text { year". }\end{array}$ \\
\hline
\end{tabular}

Basically, the interview conducted is to obtain the current recognition and disclosure of zurri waqf practices in terms of reporting aspect The respondents confirmed that the details of the zurri waqf have not been highlighted even it has been managed for centuries; as the descendants still exist as beneficiaries. For example, the acquisition and recognition of the 
MANAGEMENT SCIENCES

Vol. 11, No. 3, 2021, E-ISSN: 2225-8329 @ 2021 HRMARS

zurri waqf transaction is not detailed. It was combined with other waqf types that overshadow the existence of zurri waqf.

In addition, as the beneficiary is comprised of the descendants of the endower; then detailed reporting is not a priority of SIRC as not all the beneficiaries view the financial statements. Most beneficiaries concern on the amount of distribution that will be received but less focus on financial reporting, asset development and others.

Since zurri waqf is initiated by different endower, families and assets; it should have its own statement as the users of financial statement could clearly see the practices of zurri waqf. This has been supported by Mahamood (2020) whereby the disclosure of the zurri waqf reporting shall be prepared and disclosed as the beneficiary can take a legal action towards trustee. The current practices of zurri waqf reporting must be reviewed and improved due to the long-term financial impact on revenue generation.

As mentioned in Al- Anfaal verse 8:27:

\section{O believers! Do not betray Allah and the Messenger, nor betray your trusts knowingly.}

Whenever someone received the trust, they deem accountable to every action that they took as the consequence is bearable on them. Zurri waqf reporting shall be prepared in appropriate manners as to ensure the information disclosed is useful to the stakeholders. The discussion on the zurri waqf reporting justification is continued on the next subtopics.

\section{Theoretical underpinnings and discussion}

The discussion narrowed the scope of active accounting theory and decision usefulness theory, which are embedded in transactions or activities involving profit-making and nonprofit entities. In this case, zurri waqf is considered a non-profit activity if it is prepared by (SIRC). Regardless of the preparer; the preparation of the report should include and comply with the basic accounting theory. The goal of accounting theory is to include a set of principles and relationships that describe observed practices and predict unobserved practices. In other words, accounting theory should be able to clarify why companies prefer certain accounting methods over others, and should allow users to predict the characteristics of companies that choose different accounting methods. Like other fields, accounting theory should also be tested by accounting research (Schroeder et al., 2019)

Based on a normative theory of a set of goals, proponents recommend the way things should be. However, accountants usually do not agree on any priorities. Therefore, normative accounting theory is generally accepted only by those who agree with the assumptions on which it is based. However, most accounting assumptions are prescriptive because they focus on the goals of financial reporting (Coetsee, 2010; Schroeder et al., 2019). Positive theory attempts to explain observed phenomena and combine description, explanation, and prediction activities (Godfrey et al., 2005; Schroeder et al., 2019). They explained what was happening, but did not hint how things should be. The extreme diversity of accounting methods and implementations makes it difficult to build detailed accounting summaries. At the same time, in order to become a theory, the definition must have explanatory meaning. For example, it is necessary not only to study the use of historical costs, but also to clarify the principle of optimism used. Today, most empirical theories are related to explaining the 
MANAGEMENT SCIENCES

Vol. 11, No. 3, 2021, E-ISSN: 2225-8329 @ 2021 HRMARS

reasons for current practice and the role of predictive accounting and related knowledge in economic decision-making (Godfrey et al., 2005).

Information useful for decision-making is defined as information about the reporting entity that is useful to current and potential equity investors, lenders, and other creditors as providers of capital (IASB, 2008). Wang (2012) believes that the usefulness of decision-making is described in terms of relevance, reliability, comparability and comprehensibility. The main purpose of financial statements is to include business facts in order to make informed choices for consumers, especially investors (ASBJ, 2006). It should also increase user awareness and enable decision makers to predict future actions (Oyerinde, 2009). Bees et al., (2009) established positive financial statements, including: relevance, reliability, timeliness, comparability, comprehensiveness, comprehensibility and verifiability. It is supported by Ana (2012), who describes relevance and dependability as fundamental qualities of good accounting knowledge that can help users make better decisions. As a result, the information contained in financial reporting will be useful in making decisions involving shareholders, funders, governments, beneficiaries, and others.

When the information disclosed meets the criteria of relevance, dependability, timeliness, and comparability, it is always beneficial for decision making by stakeholders. The types of decisions vary depending on the needs of the stakeholders; for example, the disclosed rental income is classified as accrued rental income. If the accrued rental is unlikely to be reduced year after year, action will be taken against the tenants. Zurri waqf properties should be able to generate a steady stream of income in order to fulfill the deeds, the main goal of which is the survival of the family. As a result, if the income is detained by accrued issue, it will affect both the income generated and the distribution to heirs. As a result, it is required that zurri waqf reporting adhere to the basic fundamentals of positive accounting theory and decision usefulness theory in order to embark on the so close perfect reporting as it will bring more optimistic impacts towards the zurri waqf properties growth, which indirectly benefited the beneficiaries and nation.

As previously stated, positive theory and decision usefulness theory are intertwined in financial reporting in all transactions, profit or no profit. Although zurri waqf is considered less important because it is intended for the family and heirs, monetary transactions and property value must be disclosed. Assume that you have land worth by RM200,000; according to positive accounting theory, it is subject to fair value because it relates to economic decision-making about what the land will produce in the future to ensure the distribution of income to the family and their generations. 


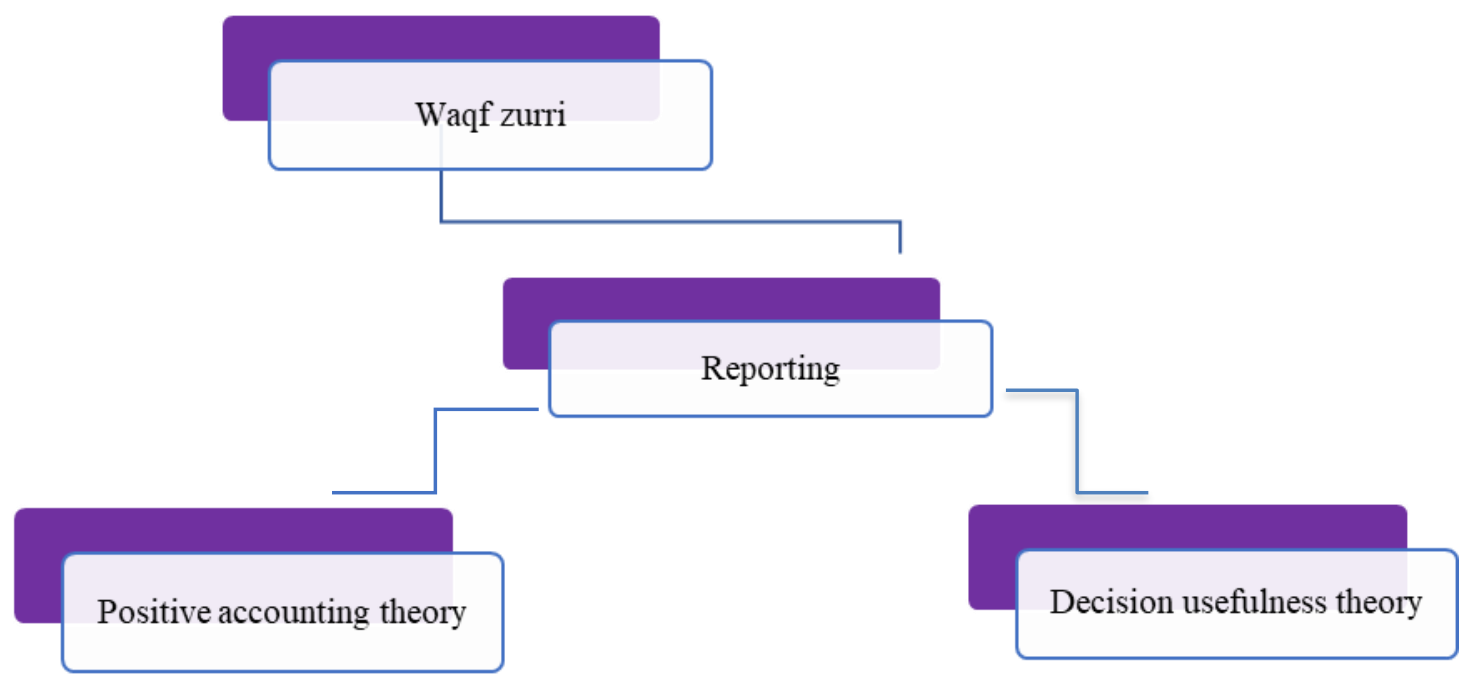

Figure ii: Accounting theories embedded in zurri waqf reporting

Table viii: Objectives and findings

\begin{tabular}{|c|c|c|}
\hline Objectives of the study & Justification & Findings \\
\hline $\begin{array}{l}\text { to examine the dislosure } \\
\text { and presentation of waqf } \\
\text { zurri in Malaysia }\end{array}$ & \multirow{2}{*}{$\begin{array}{l}\text { 1. Accountability } \\
\text { (Greiling, 2010; Gandia, } \\
\text { 2011; (Benjamin, 2012; } \\
\text { Connolly and Hyndman, } \\
\text { 2013b; Ortega- } \\
\text { Rodríguez,2020). }\end{array}$} & $\begin{array}{l}\text { There is no consistency in the } \\
\text { accounting treatment } \\
\text { particularly on the recognition } \\
\text { and disclosure of zurri waqf } \\
\text { implementation in } 3 \text { SIRCs. }\end{array}$ \\
\hline $\begin{array}{l}\text { to suggest the minimum } \\
\text { disclosure and } \\
\text { presentation of waqf } \\
\text { zurri in the annual report. }\end{array}$ & & $\begin{array}{l}\text { 1. There are } 4 \text { elements of } \\
\text { minimum disclosure: } \\
\text { a.waqf zurri } \\
\text { development } \\
\text { b.revenues on waqf zurri } \\
\text { c.allocation of waqf zurri } \\
\text { d.disclosure of assets. } \\
\text { (Md Salleh et al., 2016; Gandia, } \\
\text { 2011; MPSAS, 2013, Author, } \\
\text { 2021) } \\
\text { 2. Zurri waqf shall be treated } \\
\text { as a single unit per se based on } \\
\text { trust deed rather than } \\
\text { consolidation in a single waqf } \\
\text { fund }\end{array}$ \\
\hline
\end{tabular}

Source: Author (2021)

\section{Conclusion}

Since the nature of any profit or non-profit entity involves resources, monetary assets, expenses, and others; the reporting and compliance of the roots of accounting theory is unavoidable. Although the practice of zurri waqf is not widely practised in Malaysia; reporting 
MANAGEMENT SCIENCES

Vol. 11, No. 3, 2021, E-ISSN: 2225-8329 @ 2021 HRMARS

issues become mandatory because the uniqueness of this waqf involves permanent returns to unlimited heirs and a family. Despite active accounting theory and decision-making useful theory can be used as a guide for zurri's waqf reporting methods; it also helps to disclose accurate information and data, and can be used for stakeholders' decision-making.

This article aims to provide valuable insights into the role of annual reports in the zurri waqf reporting. It also demonstrates that the reporting has the ability to be a flexible way to fulfil the principle of multiple accountabilities, and to authorize a formal role in public accounting, as well as accountability that seems important to the internal management of SIRC. Finding reveals that there is a disclosure but still does not meet the minimum requirement and it is suggested that the loopholes may be improve in order to uphold justice and transparency. This is critical due to the sustainability of zurri's waqf property and the continuous flow of income or returns can be distributed to beneficiaries in accordance with the provisions in the deed. Not only that, when dealing with funds used for "charity", especially as Muslims, it is necessary to formulate management that emphasizes reporting and accountability elements whereby they are responsible for their actions that will be counted in the afterlife. However, there is no perfect theory can be used as a practical guide for zurri waqf.

Other theoretical ideas, both in accounting and behavioural aspects, are welcome and can be resolved when formulating the most relevant guiding theories. This article relates to zurri's waqf disclosures and reporting. Having seen the success of zurri waqf which has contributed to economic growth over the centuries; this practice can be actively promoted in Malaysia. As for zurri's waqf current reporting practices, there is still lacking information on major projects deemed to be disclosed in the annual report. This information is related to stakeholders who interested in zurri waqf. At the moment, there is no specific framework for zurri waqf reporting. As mentioned earlier, each SIRC is governed by state governments and the policies implemented by individual governments are different. This paper attaches fundamental importance to SIRC and should be a valuable resource for attempting to understand the issues surrounding waqf zurri information, particularly by finding how the element in disclosure and presentation can contributes to effective reporting.

Therefore, by recommending the minimum requirements for zurri waqf reporting; it can enrich the significant information required by relevant stakeholders, and can enhance the social participation in zurri waqf practices. Since the available literature is countable, the contribution of this article is to enrich the knowledge system, especially in the zurri waqf reporting. It also serves as a wake-up call to Muslims about the existence of wealth instruments other than existing ones. No doubt it is necessary to further examine the substance of the best guidelines for zurri waqf reporting, which require many parties to cooperate. This recommendation may further assist the administrator which in this case is SIRC to further improve the accounting treatment for zurri waqf to have standard reporting guidelines which able to uphold the zurri waqf practices as Islamic wealth instrument to preserve the equity of family, community and country as well.

\section{References}

Abdul Rahim, A. R.., Mohamad Bakar, D. And Yusuf, I. (1999), "Current practices and administration of waqf in Malaysia: a preliminary study". Awqaf Report (28/7/1999). 
MANAGEMENT SCIENCES

Vol. 11, No. 3, 2021, E-ISSN: 2225-8329 @ 2021 HRMARS

Accounting Standards Committee (1975), "The Corporate Report", London, Accounting Standards Committee.

Ahmad, H. Z. Z. 2007, "The challenges in improving the development potential of waqf lands" , Management Journal of JWHZ , Vol.1 No.1, p.13.

Al-Bukhari. (1987). "Sahih Al-Bukhari", Beirut: Dar Ibn Kathir. Al-Qardhawi.

Al-Quran Tajwid dan Terjemahan Beserta Asbabun Nuzul, Hadith Sahih dan Indeks Tematik. (2012), Penerbit Humaira Bookstore Enterprise.

Ana, L.F. (2012), "Revised qualitative characteristics of financial statement as pre-conditions for strengthening information power on capital market", Economics and organizational Journal, Vol.9 No.1.

Arshad, R., Bakar, N. A., Sakri, F. H., \& Omar, N. (2013), "Organizational characteristics and disclosure practices of non-profit organizations in Malaysia. Asian Social Science, 9(1), 209.

Beattie, V., \& Thomson, S. J. (2007), "Lifting the lid on the use of content analysis to investigate intellectual capital disclosures", Accounting Forum, Vol.31, pp.129-163.

Bees, F.V., Braam,G., \& Boelens, S. (2009), "Quality of financial reporting: measuring qualitative characteristics", NICE working paper, Vol. 9 No. 108, pp.1-41.

Benjamin, L. M. (2012), "The Potential of Outcome Measurement for Strengthening Nonprofits' Accountability to Beneficiaries", Nonprofit and Voluntary Sector Quarterly, Vol.42 No.6, pp.1224-1244.

Breckell, P., Harrison, K. and Robert, N., (2010), "Impact reporting in the UK charity sector", CFDG, Charity Finance Directors' Group.

Charity Commission (2000), "Accounting and Reporting by Charities: Statement of Recommended Practice", London: Charity Commission.

Cizakca, M. (1998), "Awqaf in history and its implications for modern Islamic economies", Islamic Economic Studies, Vol.6 No.1.

Coetsee, D. (2010), "The role of accounting theory in the development of accounting principles. Meditari: Research Journal of the School of Accounting Sciences, 18(1), 1-16.

Connolly, C., \&Hyndman,N., (2013b), "Towards charity accountability: Narrowing the gap between provision and needs?", Public Management Review, Vol.15 No.1, pp.1-24.

Cordery, C., \& Deguchi, M. (2018), "Charity registration and reporting: a cross-jurisdictional and theoretical analysis of regulatory impact", Public Management Review, Vol.20 No.9, pp.1332-1352.

Daud. D. (2019), "The role of Islamic governance in the reinforcement waqf reporting: SIRC Malaysia case", Journal of Islamic Accounting and Business Research, Vol.10 No.3, pp.392-406.

Doumani B. (1998), “Endowing family: Waqf, property devolution, and gender in greater Syria, 1800 to 1860 ", Comparative studies in society and history, Vol. 40 No.1, pp.3-41.

Suhaimi, F. M. (2018), "Wakaf Ahli: Peruntukan Undang-Undang Dan Pelaksanaannya Di Malaysia", Malaysian Journal of Syariah and law, pp.73-81.

FASB. (1975), "Statement of Financial Accounting Concepts", Norwalk, Connecticut: Financial Accounting Standard Board.

Gandia, J. L. (2011), "Internet disclosure by nonprofit organizations: Empirical evidence of nongovernmental organizations for development in Spain", Nonprofit and voluntary sector quarterly, Vol.40 No.1, pp.57-78.

Greiling, D., \& Spraul, K. (2010), "Accountability and the challenges of information disclosure”, Public Administration Quarterly, pp.338-377. 
MANAGEMENT SCIENCES

Vol. 11, No. 3, 2021, E-ISSN: 2225-8329 @ 2021 HRMARS

Basri, H. A., \& Nabihah, S. (2010), "Towards Good Accountability : The Role of Accounting in Islamic Religious Organisations". World Academy of Science, Engineering and Technology, pp.1133-1139.

Healy, P. M., \& Palepu, K. G. (2001), "Information asymmetry, corporate disclosure, and the capital markets: A review of the empirical disclosure literature", Journal of accounting and economics, Vol.31 No.1-3, pp.405-440.

Hossain, M., \& Hammami, H. (2009), "Voluntary disclosure in the annual reports of an emerging country: The case of Qatar", Advances in Accounting, Vol. 25 No.2, pp.255265.

Hyndman, N., \& McConville, D. (2016), “Transparency in Reporting on Charities' Efficiency: A Framework for Analysis". Nonprofit and Voluntary Sector Quarterly, Vol.45 No.4, pp.844-865.

Hyndman, N., \& McConville, D. (2016), "Transparency in Reporting on Charities' Efficiency: A Framework for Analysis", Nonprofit and Voluntary Sector Quarterly, Vol.45 No.4, pp.844-865.

IASB. (2008), "An improved conceptual framework for financial reporting".

ljiri, Y. (1975), "Studies in accounting research \#10: Theory of Accounting Measurement", American Accounting Association: Sarasota.

J. A. N. M. (2013), "Piawaian perakaunan sektor awam Malaysia (Malaysian public sector accounting standards) MPSAS 1 Hasil daripada urus niaga pertukaran", Putrajaya: JANM.

Jeavons, T. (1994a), "When the bottom line is faithfulness: Management of Christian service organizations", Bloomington: Indiana University Press.

Joseph, S. (2015). "Islamic law and the management of natural resources in seventeenth and eighteenth century Ottoman Syria."Environment and History", Vol.21 No.2, pp.227-256.

Kelly, K. S. (1998), "Effective fund-raising management", Mahwah, NJ: Lawrence Erlbaum Associates.

Kelly, K. S. (2001a), "ROPES: A model of the fund-raising process. In J. M. Greenfield (Ed.)", The nonprofit handbook: Fundraising, New York, NY: John Wiley \& Sons. pp. 96-116.

Kelly, K. S. (2001b), "Stewardship: The fifth step in the public relations pro- cess. In R. L. Heath, \& G. Vasquez (Eds.)", Handbook of public relations, Thousand Oaks, CA: Sage Publications, pp. 279-289

Krippendorff, K. (2013), "Content Analysis: An Introduction to its Methodology (3rd ed.)", California: Sage. Lumley.

Kyngäs, H. (2020), "Qualitative research and content analysis. In The application of content analysis in nursing science research", Springer, Cham, pp. 3-11.

Latridis, G., \& Konstantia, D. (2011), "The Impact of IFRS Implementation on Greek Listed Companies", International Journal of Managerial Finance, Vol.7 No.3.

Layish, A. (2008), "Waqfs of Awlād al-Nās in Aleppo in the Late Mamlūk Period as Reflected in a Family Archive", Journal of the Economic and Social History of the Orient, Vol.51 No.2, 287-326.

Li, P., Men, L. R., \& Yue, C. A. (2020), "An exploratory study of stewardship for Chinese nonprofit organizations", International Journal of Nonprofit and Voluntary Sector Marketing, Vol.25 No.2, pp.1-12.

Li, P., Men, L. R., \& Yue, C. A. (2020), “An exploratory study of stewardship for Chinese nonprofit organizations", International Journal of Nonprofit and Voluntary Sector Marketing, Vol.25 No.2,pp. 1-12. 
MANAGEMENT SCIENCES

Vol. 11, No. 3, 2021, E-ISSN: 2225-8329 @ 2021 HRMARS

Lienhardt, P. (1966), "Family waqf in Zanzibar" ,Journal of the Anthropological Society of Oxford, Vol.17, pp.96-106.

Mahamood, S. M. (2006), "Waqf in Malaysia: Legal and administrative perspectives", University of Malaya Press.

Mahamood, S.M. (2020). "Wakaf zuriat: Instrumen Memperkasa Ekonomi Keluarga". Webinar, platform:Googlemeet.

Manat, A. B. (2007), "Current issues related to the development of waqf land" , Management Journal of JWHZ, Vol.1 No. 1, pp. 53-71.

Masruki, R. and Shafii, Z. (2013), "The development of waqf accounting in enhancing accountability", Middle-East Journal of Scientific Research, Vol. 13 No. 13, pp. 1-6.

Massimo Contrafatto (2014). "Stewardship Theory: Approaches and Perspectives". In Accountability and social accounting for social and non-profit organizations. Emerald Group Publishing Limited.

Salleh, M. F., Basnan, N., Ahmad, A., Harun, A., Naim, M. A., \& Wahid, H. (2016), "Cadangan item pendedahan bagi pelaporan institusi wakaf, zakat dan baitulmal", IPN Journal of Research and Practice in Public Sector Accounting and Management, pp. 23-44.

Md. Zain, S.R. (2005), "Determinants of financial reporting practices on waqf by Malaysian state islamic religious council in Malaysia", Unpublished Masters Dissertation, International Islamic University Malaysia, Kuala Lumpur.

Menage, V. L. (1990). "Haim Gerber: Economy and society in an Ottoman city: Bursa, 16001700. (The Max Schloessinger Memorial Series, monograph in.) vi, 227 pp. Jerusalem: The Hebrew University, 1988." Bulletin of the School of Oriental and African Studies 53, no.1,: 143-145.

Morse, J. M. (2000), "Determining sample size", Qualitative Health Research : 3-5.

Muis. (2019), "Majlis Ugama Islam Singapura", available at www.muis.gov.sg,(accessed at. https://www.muis.gov.sg/).

O' Connell, V. (2007), "Reflections on stewardship reporting", Accounting Horizons, Vol.21 No.2, pp.215-227.

Ortega-Rodríguez, C., Licerán-Gutiérrez, A., \& Moreno-Albarracín, A. L. (2020), "Transparency as a key element in accountability in non-profit organizations: A systematic literature review:, Sustainability, Vol.12 No.14, p.5834.

Oyerinde, O. T. (2009), "Value-relevance of accounting information in emerging stock market in Nigeria", Proceedings of the 10th Annual International Academy of African business and Development (IAABD), Uganda.

Parsons, L. M., Baker, T. L., Buchheit, S. R., Sealy, C. L., Stinson, S. R., \& Thayer, J. M. (2020), "Donors, Distance, And The Influence Of Accounting Information" submitted in partial fulfillment of the requirements for the degree of Doctor of Philosophy, Department of Accounting in the Graduate School of The University of Alabama.

Pressgrove, G., \& Kim, C. (2018), "Stewardship, credibility and political communications: A content analysis of the 2016 election", Public Relations Review, Vol.44 No.2, pp.247255.

Patton, M. Q. (1990), "Qualitative Evaluation and Research Methods, California": SAGE Publications.

Reiter, Y. (1995), "Family waqf entitlements in British Palestine (1917-1948)", Islamic Law and Society, Vol.2 No. 2, pp.174-193.

Respondent A,B,C,D,E (2020), "Pelaksanaan wakaf zurri di Malaysia”, SIRC's interview, January - July. 
MANAGEMENT SCIENCES

Vol. 11, No. 3, 2021, E-ISSN: 2225-8329 @ 2021 HRMARS

Sadique, M. A., Ansari, A. H., Hingun, M., \& Hasan, A. (2018), "Socio-Legal Significance of Family Waqf in Islamic Law: Its Degeneration and Revival", IIUM Law Journal, Vol. 24 No.2, pp.309-334.

Schneider, J. A. (2013), "Comparing Stewardship Across Faith-Based Organizations”, Nonprofit and Voluntary Sector Quarterly, Vol.42 No.3, pp.517-539.

Schroeder, R. G., Clark, M. W., \& Cathey, J. M. (2005)., "Financial Accounting Theory and Analysis".

Siraj, S. A. (2012), "An empirical investigation into the accounting, accountability and effectiveness of waqf management in the State Islamic Religious Councils (SIRCS) in Malaysia", Doctoral dissertation, Cardiff University.

Soyinka', K. A., Fagbayimu, M. O., Adegoroye, E., \& Ogunmola, J. O. (2017), “Decision usefulness and financial reporting: the general public perspective".

State Islamic Religious Council (2017), "Annual report", Malaysia.

Stibbard, P., Russell, D., \& Bromley, B. (2012), "Understanding the waqf in the world of the trust", Trusts \& Trustees, Vol.18 No. 8, pp.785-810.

Talib, N. A., Latiff, R. A., Aman, A., \& Palil, M. R. (2018), “An exploratory study of accounting and reporting practice for waqf among State Accounting Standards Board of Japan (ASBJ)", Discussion Paper, Conceptual Framework of Financial Accounting.

Tjek. T. (2013), "Wakaf Ahli Dalam Konsep Fikih Tradisional”, Jurnal Al-Irsyad Vol. 2, pp. 81-91

Vejzagic, M. (2012), "The concept of corporate reporting from an islamic perspective: an overview", Academia. edu.

Vinnicombe, T. (2012). A study of compliance with AAOIFI accounting standards by Islamic banks in Bahrain. Journal of Islamic Accounting and Business Research.

Wang, H. (2012), "The decision usefulness of fair value accounting in the debt market", Thesis submitted to Post Graduate School, University of Concordia, Canada. 